\title{
Effect of Immersion in Cold Water on Creatine Kinase and Myoglobin Levels in Soccer Players
}

\section{Efeito da Imersão em Água Fria sobre os Níveis de Creatinoquinase e Mioglobina de Atletas de Futebol}

\author{
Fernanda Bortolo Pesenti*a; Eduardo Rossi Spartalis ${ }^{\mathrm{b}}$; Alessandra Miyuki Okino ${ }^{\mathrm{c}}$; Danielle Venturinic; \\ Ariobaldo Frisselic; Christiane de Souza Guerino Macedo ${ }^{\mathrm{a}}$
}

\author{
${ }^{a}$ State University of Londrina, Postgraduate Program in Rehabilitation Sciences. PR, Brasil. \\ ${ }^{\mathrm{b} S}$ State University of Londrina, Laboratory of Teaching, Research and Extension in Sports Physiotherapy. PR, Brazil. \\ 'State University of Londrina, Department of Physical Education and Sport. PR, Brazil. \\ *E-mail: fernanda pesenti@hotmail.com \\ Recebido em: 30/01/2020 \\ Aprovado em: 05/05/2020
}

\begin{abstract}
The objective of this study was to analyze the effect of body immersion in cold water on creatine kinase and myoglobin levels in soccer athletes. For this, 10 soccer players aged between 16 and 18 years old, submitted to 5 blood samples, were analyzed: fasting, post-match, after 24,48 and 72 hours. At the end of the match they were randomized into intervention group (GI) and control (CG). GI immersion in cold water, water plate at the level of the iliac crests, $10^{\circ} \mathrm{C}$, for 10 minutes and the $\mathrm{GC}$ immersed in water at room temperature at the same height and for the same period of time. The levels of creatine kinase did not change in the analyzed groups and moments. Myoglobin levels increased significantly after the match and returned to baseline after 24 and 72 hours, with a peak in 48 hours. There was no difference between the intervention groups at all the evaluated moments. It was concluded that immersion in cold water did not alter the creatine kinase and myoglobin levels in relation to the control group in soccer athletes, indicating that for this population immersion in cold water was not able to reduce muscle damage after exercise.
\end{abstract}

Keywords: Athletic Injuries. Myalgia. Fatigue. Cryotherapy.

\section{Resumo}

O objetivo deste estudo foi analisar o efeito da imersão corporal em água fria nos níveis de creatinoquinase e mioglobina em atletas de futebol. Para isto, foram analisados 10 atletas de futebol com idade entre 16 e 18 anos, submetidos à 5 coletas sanguíneas: em jejum, após jogo, após 24, 48 e 72 horas. Ao término do jogo foram aleatorizados em grupo intervenção (GI) e controle (GC). O GI realizou imersão em água fria, lâmina da água à altura das cristas ilíacas, $10^{\circ} \mathrm{C}$, por 10 minutos e o GC realizou imersão em água à temperatura ambiente à mesma altura e durante o mesmo periodo de tempo. Os níveis de creatinoquinase não apresentaram alteração nos grupos e momentos analisados. Já os níveis de mioglobina aumentaram significativamente após o jogo e retornaram aos valores basais após 24 e 72 horas, com pico em 48 horas. Não houve diferença entre os grupos de intervenção em todos os momentos avaliados. Conclui-se então que a imersão em água fria não alterou os niveis de creatinoquinase e mioglobina em relação ao grupo controle em atletas de futebol, indicando que para esta população a imersão em água fria não foi capaz de reduzir o dano muscular após exercício.

Palavras-chave: Traumatismos em Atletas. Mialgia. Fadiga. Crioterapia.

\section{Introduction}

Soccer is a complex physical activity that requires the athlete to develop maximum physical skills due to the wide motor demand, in which athletes must be prepared tactical, physical and technically ${ }^{1}$. Physical activity is intermittent and requires a variety of energy sources, as it switches high, medium and low intensity runs, as well as muscular strength and power demands, jumps, side runs, changes of direction and recovery periods with low intensity, continuous runs and walks.

In an attempt to point out muscle damage after intense training, creatine kinase (CK) and myoglobin levels are analyzed, characterized as markers of muscle membrane damage. This analysis is justified because these molecules are cytoplasmic and do not have the ability to cross the sarcoplasmic membrane barrier ${ }^{2}$. Therefore, the increase in serum concentration of these molecules is used as a damage indication to the muscle membrane and other tissue structures.

Among these molecules, CK is often described as the best indirect marker of muscle tissue damage, especially after strength exercise or other exercises that require predominantly eccentric actions (jumps, sudden stops, etc.), and can be found in three forms: muscle creatine kinase (CK-MM), cardiac creatine kinase (CK-MB) and cerebral creatine kinase (CK-BB), being CK-MM bound to the myofibrils structure and, therefore, used to point out muscle damage ${ }^{3}$. Whereas myoglobin is used to store oxygen in muscle cells and acts combined with CK-MM (4). Thus, when the athlete engages in rigorous exercise, the skeletal muscle suffers micro lesions due to oxygen deficiency, which can alter the CK-MM and 
myoglobin levels.

One way to control the elevation of levels of blood inflammatory markers is immersion in cold water. This resource has been used for decades as a post-exercise recovery strategy in a variety of sports. The application of cold decreases pain and muscle spasms, reduces the inflammatory process and helps recovery after trauma ${ }^{5-7}$. Recent guidelines suggest that reducing skin temperature to less than 12 degrees $\mathrm{C}$ is efficient in the development of analgesia; Also, temperatures between 11 and 15 degrees $C$ are used for analgesic and tissue recovery purposes ${ }^{8}$.

However, even with the great use of immersion in cold water to control blood markers levels of muscle injury in the sport, the analysis of the existing literature has not establish a consensus or data to reliably support this intervention ${ }^{9}$ yet, which points to a gap in the literature and the need for further studies in the area. Thus, the objective of the present study was to analyze the effect of body immersion in cold water on blood markers of muscle injury in soccer athletes and to establish its alterations after 24,48 and 72 hours of intervention.

\section{Material and Methods}

\subsection{Ethical aspects}

The project was approved by the Research Ethics Committee of State University of Londrina (Opinion 00121/2013).

The power of the test was raised with the Power and sample Size program, 95\% confidence interval and 5\% alpha, considering the mean and standard deviation of myoglobin data in this study and established in 1 as high power.

\subsection{Sample}

The sample was convenience and comprised 10 soccer athletes, male, midfielders, forwards, defensive midfielders and defenders, with training five times a week, aged between 16 and 18 years, who participated in at least $50 \%$ of a state championship match, no complaints of musculoskeletal pain or history of muscle injury in the last six months. As exclusion criteria, athletes with vascular problems were considered, since it is where cold water immersion is contraindicated, with cold allergy, with lower limb surgery in the last six months and with viral symptoms (such as the flu or cold).

\subsection{Data collection}

Data collection was performed at three different moments, the first for basal data of athletes, and fatigue induction, and the others for blood collection and symptoms follow-up, as shown in Figure 1.
Figure 1 - Moments of data collection in flowchart

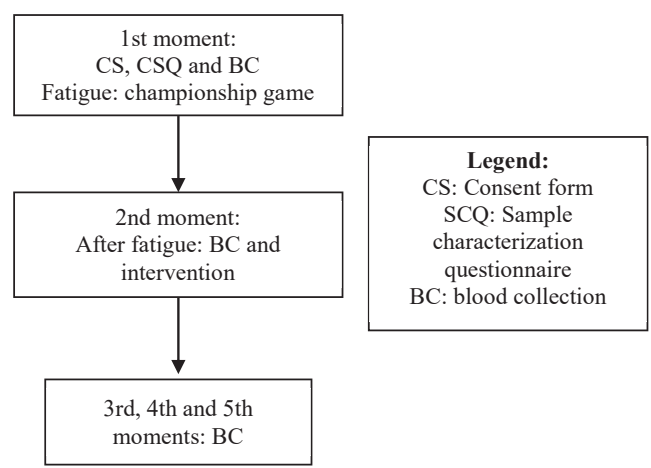

Source: Research data.

\section{First moment of collection}

Initially the athletes received all information about the research, signed the informed consent form and responded to the sample characterization questionnaire with data on age, weight, height, position of play, time of soccer practice, number of training per week and previous injuries.

The first blood collection was then performed for the analysis of creatine kinase (CK) and myoglobin levels. The athletes were fasting, sitting in a comfortable chair, with their arm resting on a support positioned about the height of their shoulders. The arm was garroted at the midpoint of the humerus, sterilized with $70 \%$ alcohol-soaked cotton, and punctured with a disposable $25 \times 8 \mathrm{~mm}$ needle at that site. Venous blood was aspirated in a vacuum collection tube with a capacity of $5 \mathrm{~mL}$ each, containing separator gel without anticoagulant for myoglobin and CK tests. The needles were safely discarded, as all the other contaminated disposable materials were, according to the standard procedure of the clinical analysis laboratory at the University Hospital of UEL. Laboratory test determinations were developed in a Dimension RXL Max - Siemens ${ }^{\circledR}$ biochemical Autoanalyzer system. The determinations used methods established in the medical literature and were carried out according to the manufacturers' protocols. Blood samples and analyzes were re-analyzed by trained and blinded evaluators.

Late muscular pain induction protocol

As a fatigue protocol, all the athletes participated in a state championship match, as proposed by Ascensão ${ }^{10}$.

Second moment of collection

Immediately after the end of the match, still in the stadium, the second blood collection was performed and, in sequence, the athletes drew the type of intervention they would be submitted to, immersion in cold water or immersion in water at room temperature. The immersion group in cold water was submitted to immersion in water up to the height of the Anterior superior iliac spines at a temperature of $10^{\circ} \mathrm{C}$ for 10 minutes, as proposed by Machado et $\mathrm{al}^{8}$. The control group was submitted to immersion in water at room temperature, up to the height of the Anterior superior iliac spines, also for 10 minutes ${ }^{10}$. 
Third, fourth and fifth moment of collection

Blood collection was again performed after 24, 48 and 72 hours.

\subsection{Data analysis}

After the blood tests were processed, the results were organized in tables for the cryoimmersion and control groups. The results for the moments were established: fasting, immediately after the match, after 24, 48 and 72 hours. Shapiro Wilk's test was used for normality analysis and Bonferroni's ANOVA and post hoc test were used to analyze the differences within the same group. The comparison among the groups was established by the $t$ test for independent samples. Also, the difference between fasting values and other sampling moments was calculated. The significance level was set at 5\% and SPSS ${ }^{\circledR} 20$ was used for data analysis.

\section{Results and Discussion}

In total, 10 athletes participated in the study. The control group was composed of five soccer athletes, aged $16.8 \pm 0.83$ years, weighing $72 \pm 5.04$ kilograms, height of $1.79 \pm 0.05$ meters, who practiced soccer for $9,4 \pm 1,94$ years and remained $78.8 \pm 11.73$ minutes at the soccer match in which they were evaluated. Whereas in the intervention group, the five athletes were $17.6 \pm 0.54$ years old, $74.4 \pm 7.16$ kilograms, $1.79 \pm 0.09$ meters, practiced soccer for $9.2 \pm 3.56$ years and remained for $83.4 \pm 9.09$ minutes at the match, with no significant differences among the groups for these variables.

The CK analysis did not make any difference between the sampling moments and intervention groups. However, a difference was detected for myoglobin in both groups when the fasting athletes' values were compared to those after the match, as well as in 72 hours, after the training was returned (Table 1).

Table 1 - Results of the creatine kinase and myoglobin analysis in soccer athletes submitted to cold water immersion and control

\begin{tabular}{|c|c|c|c|c|c|c|c|}
\hline \multirow{2}{*}{$\begin{array}{c}\text { Blood } \\
\text { Parameters } \\
\text { Evaluated }\end{array}$} & Groups & \multicolumn{3}{|c|}{ Moment of Blood Collection } \\
\cline { 3 - 7 } & & $\begin{array}{c}\text { Fasting } \\
\text { (Basal) }\end{array}$ & After the match & After 24 hours & After 48 hours & After 72 hours & $\begin{array}{c}\text { P } \\
\text { Anova }\end{array}$ \\
\hline CK & $\begin{array}{c}\text { Immersion in cold } \\
\text { water } \\
\text { Control }\end{array}$ & $504(301.02)$ & $641(250.33)$ & $601(179.72)$ & $495.50(89.94)$ & $459.25(140.83)$ & 0.976 \\
\hline \multirow{2}{*}{ Myoglobin } & $\begin{array}{c}\text { Immersion in cold } \\
\text { water }\end{array}$ & $51.25(11.95)^{*}$ & $231.75(7.80)^{* *}$ & $41(17.28)^{\#}$ & $116.75(84.78)^{*}$ & $66.75(29.60)^{\#}$ & 0.011 \\
& Control & $55.25(2.06)^{*}$ & $274.75(73.14)^{* \#}$ & $55(10.09)^{\#}$ & $256.00(120.36)^{*}$ & $99.25(44.24)^{\#}$ & 0.000 \\
\hline
\end{tabular}

*Significant difference compared to fasting moment.

\#Significant difference compared to post- match moment.

Source: Research data.

After the data analysis at the different collection moments, the difference between $\mathrm{CK}$ and myoglobin values was established for the groups submitted to cold water immersion and control (Figures 2 and 3 ).

Figure 2 - Analysis of the differences found for creatine kinase among the fasting values with different collection moments in both intervention groups

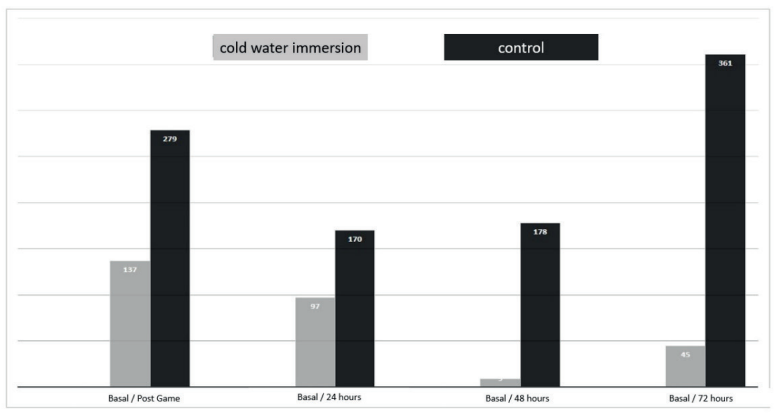

Source: Research data.
Figure 3 - Analysis of the differences found for Myoglobin among the fasting values with different collection moments in both intervention groups

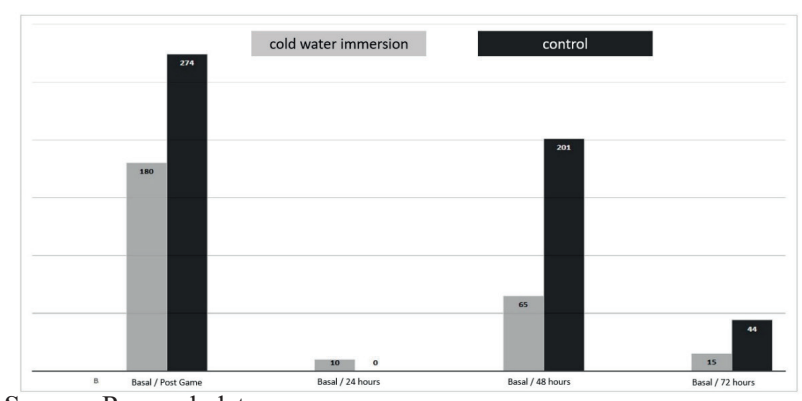

Source: Research data.

Since the literature is still controversial regarding the real effects of cold-water immersion on inflammatory blood markers of muscle injury, new studies have emerged to obtain enlightening responses on the subject. However, the inferences raised about $\mathrm{CK}$ values may be more reliable when 
their kinetics are associated with that of other physiological stress $^{11}$.

The results of the present study did not establish differences among the groups submitted to cold water immersion or control for CK and myoglobin levels, as well as the results of Vanderlei ${ }^{12}$, where athletes were submitted to cold water immersion at $10^{\circ} \mathrm{C}$. It is worth noting that $\mathrm{CK}$ and myoglobin values were always lower in the group submitted to cold water immersion, but the significant difference was not established, perhaps due to the small number of athletes analyzed or by water temperature.

In addition, Baylei ${ }^{13}$ established that cryoimmersion had no response in creatine kinase concentration, as in the present study, but myoglobin reduction was observed one hour after exercise.

Also, Sellwood ${ }^{14}$ after the application of cryoimmersion concluded that the protocol was ineffective in reducing $\mathrm{CK}$ and myoglobin markers in untrained individuals, a result similar to that found in this study, and questions the broad use of this intervention as a recovery strategy for athletes.

Cassar $^{15}$ points out that there is some evidence that cryotherapy reduces the plasma activity of creatine kinase, as well as the symptoms related to pain and muscle stiffness ${ }^{16}$. The possible explanation for this decrease is based on the reduction of inflammatory response, through constriction of capillary vessels, reductions in capillary permeability and blood flow ${ }^{17}$.

Unlike Vanderlei ${ }^{12}$ and Goodall and Howatson ${ }^{18}$ who found the CK peak within 24 hours after fatigue, this study found the peak concentration of this marker in 48 hours, but with return to baseline within 72 hours as well as these authors. It is believed that the divergence of results in relation to $\mathrm{CK}$ and myoglobin are due to the different methodologies of the studies.

In the present study, the routine of the athletes' matches and training was respected so that the results were as close to the actual and reproducible as possible. Thus, after the first game, a significant increase in CK and myoglobin values was observed, which reduced in 24 hours when athletes remained at rest. In the follow-up, a significant increase can be observed in 48 hours, when athletes returned to the training routine, and again reduction in 72 hours. Thus, showing that after intense matches or training there is a need for rest for these values to return to baseline, moreover, it indicates that even when submitted to intervention for fatigue recovery, in return to the training routine there is an increase of these variables.

\section{Conclusion}

Based on the results of this study and previous studies, athletes can benefit from cold water immersion in view of pain perception responses, however, for blood markers there is still no consensus. There is therefore a need for further studies in the area for further clarification.

\section{Acknowledgements}

To the Laboratory of Clinical Analysis of the University Hospital of the State University of Londrina - HUUEL

\section{References}

1 Hoff, J. Training and testing physical capacities for elite soccer players. J Sports Scie 2005;23(6):573-82. doi: https:// doi.org/10.1080/02640410400021252

2 Brown SJ, Child RB, Day SH, Donnelly AE. Exerciseinduced skeletal muscle damage and adaptation following repeated bouts of eccentric muscle contractions. J Sports Scie 1997;15(2):215-22. doi: https://doi. org/10.1080/026404197367498

3 Kristjansson RP, Oddsson A, Helgason H, Sveinbjornsson G, Arnadottir GA, Jensson BO, et al. Common and rare variants associating with serum levels of creatine kinase and lactate dehydrogenase. Nat Communic 2006;7. doi: https://doi. org/10.1038/ncomms 10572

4 SchlaterAE, MirandaMA, Frye MA, Trumble SJ, Kanatous SB. Changing the paradigm for myoglobin: a novel link between lipids and myoglobin. J Appl Physiol 2014;117(3):307-15. doi: https://doi.org/10.1152/japplphysiol.00973.2013

5 Macedo CSG, Vicente RC, Cesário MD, Guirro RRDJ. Coldwater immersion alters muscle recruitment and balance of basketball players during vertical jump landing. J Sports Scie. 2016; 34(4):348-57. doi: https://doi.org/10.1080/02640414.2 015.1054861

6 Alonso CS, Macedo CDSG, Jesus Guirro RR. Efeito da crioterapia na resposta eletromiográfica dos músculos tibial anterior, fibular longo e gastrocnemio lateral de atletas após o movimento de inversão do tornozelo. Fisioter Pesq 2013;20(4):316-21. doi: https://doi.org/10.1590/S180929502013000400003

7 Banfi G, Lombardi G, Colombini A, Melegati G. Whole-body cryotherapy in athletes. Sports Med 2010;40(6):509-17. doi: https://doi.org/10.2165/11531940-000000000-00000

8 Machado AF, Ferreira PH, Micheletti JK, Almeida AC, Lemes ÍR, Vanderlei FM et al. Can water temperature and immersion time influence the effect of cold water immersion on muscle soreness? A systematic review and meta-analysis. Sports Med 2016;46(4):503-14. doi: https://doi.org/10.1007/s40279-0150431-7

9 Peake J, Roberts L, Raastad T, Figueiredo V, Cameron-Smith $\mathrm{D}$, Coombes J, et al. The effects of cold water immersion on inflammation, growth and neurotrophic factors in skeletal muscle after resistance exercise. FASEB J 2016;30:1291-4. doi: https://www.fasebj.org/doi/abs/10.1096/fasebj.30.1_ supplement.1291.4

10 Ascensao A, Leite M, Rebelo AN, Magalhäes S, Magalhäes J. Effects of cold water immersion on the recovery of physical performance and muscle damage following a one-off soccer match. J Sports Scie 2011;29(3):217-25. doi: https://doi.org/1 $0.1080 / 02640414.2010 .526132$

11 Costa HA, Rabelo AS. O uso da CK como marcador de estresse fisiológico no esporte. RBPFEX Rev Bras Presc Fisiol Exerc 2016, 9(54):371-4. doi: http://www.rbpfex.com. br/index.php/rbpfex/article/download/1077/713.

12 Vanderlei FM, Machado AF, Netto JJ, Pastre CM. Postexercise recovery of biological, clinical and metabolic variables after different temperatures and durations of cold water immersion: a randomized clinical trial. J Sports Med 
Phys Fitness 2017;57(10):1267-75. doi: https://10.23736/ s0022-4707.17.06841-4

13 Bailey DM, Erith SJ, Griffin PJ, Dowson A, Brewer DS, Gant, N, et al. Influence of cold-water immersion on indices of muscle damage following prolonged intermittent shuttle running. J Sports Scie 2007;25(11):1163-70. doi: https://doi. org/10.1080/02640410600982659

14 Sellwood KL, Brukner P, Williams D, Nicol A, Hinman R. Ice-water immersion and delayed-onset muscle soreness: a randomised controlled trial. British J Sports Med 2007;41(6):392-7. doi: http://dx.doi.org/10.1136/ bjsm.2006.033985

15 Cassar S, Kidgell D, Pearce A. The effect of hydrotherapy recovery on central fatigue: A preliminary examination using transcranial magnetic stimulation. J Scie Med Sport 2010, 12, e53. doi: https://doi.org/10.1016/j.jsams.2009.10.111

16 Burgess TL, Lambert MI. The efficacy of cryotherapy on recovery following exercise-induced muscle damage: invited review article. Int Sport Med J 2010;11(2):258-77. doi: https://journals.co.za/content/ismj/11/2/EJC48394\#abstract content

17 Eston R, Peters D. Effects of cold water immersion on the symptoms of exercise-induced muscle damage. J Sports Scie 1999;17(3):231-8. doi: https://doi. org/10.1080/026404199366136

18 Goodall S, Howatson G. The effects of multiple cold water immersions on indices of muscle damage. J Sports Scie Med 2008;7(2):235. 